\title{
18
}

\section{ONTOLOGICAL SECURITY, GLOBALIZATION, AND GEOGRAPHICAL IMAGINATION}

\author{
Ilse Helbrecht, Janina Dobrusskin, \\ Carolin Genz, and Lucas Pohl
}

\section{Globalization anxieties from a geographical perspective}

In the year 2016, the majority of the British people voted in a referendum to leave the European Union. The results of the national election in 2019 strongly reaffirmed this Brexit vote, and by now, the UK has already left the EU. At the same time, Donald Trump governs the United States of America with a new policy of "America First," thereby shaking up the geopolitical order and demanding new foreign, trade, and military politics from most of its partners around the globe. On the same note, the global corona pandemic has provoked a widespread closing of national borders and a preliminary end of globalization "as we know it." While many states and governments are predominantly engaged in reorienting their geopolitical positioning as a result, people from various crisis regions are increasingly claiming political asylum in areas such as the United States or Europe. Civil wars and both social and democratic uprisings in Syria, Sudan, Afghanistan, and Iran have created a global refugee population, caused and accompanied by enormous human suffering through war crimes and forced displacement. Hence, millions of refugees are attempting to come by foot, boat, bus, or train in a desperate effort to enter the EU and the US-risking their lives at the harsh, ever more militarized borders of the West. And even more refugees live in "indefinite exile" in refugee camps across the global South, only poorly provided by the UNHRC like in Jordan or Kenya (Hyndman and Giles 2016, 2).

Yet, whereas Western countries are viewed as safe havens from the perspective of international refugees, within Europe and North America new anxieties are being stirred against economic and political globalization as well as international migration. A strong right-wing populism has arisen, with populist (party) leaders like Marie Le Pen in France, Matteo Salvini in Italy, or Björn Höcke in Germany, who are promising safety for "their" people. Based on empirical evidence, the latter can 
even legally be called a "fascist," as ruled recently by a German court (Verwaltungsgericht Meiningen 2019). This national populism has been institutionalized, either in new political parties all over Europe like the "Front National" in France, the "Lega Nord" in Italy, or the "Alternative für Deutschland" in Germany, or it has captured traditional, established parties like the "Republicans" headed by Donald Trump. Sadly enough, racism, sexism, homophobia, and islamophobia are (back) on the agenda. And it is through mechanisms of fear, of rising anxiety towards "the stranger" or "the other" — which can be the refugee, the migrant, or your neighbor next door - that new waves of nationalism and territorial security policies are legitimized. Hence, whereas the 20th century ended with the hopeful fall of the Berlin Wall and the termination of the Cold War, the beginning of the 21st century is marked by revanchist movements of right-wing populism, the erection of new (state and cultural) borders, and the return of xenophobia, of fear towards the stranger.

We argue that what seems like a paradox at first glance-the simultaneous existence of consummate globalization, on one hand, and the rise of xenophobic nationalism, on the other hand - is structurally linked. After all, it is not by accident that (economic) globalization irritates national identities or even deeply unsettles personal identities (Anselmi 2018; Steger and James 2019). Quite the opposite, we suggest, it is in fact the personal and deeply emotional level of the subject that is strongly affected by globalization, i.e. processes of increasing exchange and interaction on a global scale (Nagar et al. 2002; Kinnvall 2004; Matthews and Sidhu 2005; Sassen 2013; Dirksmeier and Helbrecht 2015a). It is the basic trust of people in the continuity of their identity, the continuity of their life, and the continuity of their environment - in a nutshell: their ontological security (Laing 1990; Giddens 1991) — that is challenged and at times even highly at risk through globalization. Thus, rising ontological insecurity can partially contribute to the emergence of new nationalist populist currents, besides other factors such as political persuasions.

These far-reaching effects of globalization on personal affects and identities have to be scrutinized (Dirksmeier and Helbrecht 2015b) if we are to understand the sweeping changes of national sentiment and international resentment that can be observed in many countries worldwide. Thus, we uphold the argument that it is only through a multiscale analysis, combining the most intimate scale of personal development and psychological processes, on one hand, with broader national political discourses and/or global formations, on the other hand, that we can fully understand the (re)emergence of nationalism, racism, and xenophobia. Certainly, this is exactly what feminist scholars have long argued for: applying an embodied, feminist perspective to geopolitics and political geography (Hyndman 2004; 2019).

Therefore, in this chapter, we aim to explore some of the geographical depth in these anxieties. What are we afraid of in times of globalization? Which kind of insecurity is raised through the continuously intensifying processes of economic exchange, international migration, and communication? And, more importantly, how do we reassure ourselves in times of disorienting societal dynamics? Which spatial routines, practices, places, and imaginations help us to stabilize our own 
identities and the positioning of self in such a dynamically changing world? Because fully understanding the complete picture of the globalization-anxiety complex is required in order to grapple with it, address it politically and culturally, and, thus, help overcome the fatal return of xenophobia, racism, and their likes.

It was Anthony Giddens who first addressed these pressing questions. As early as 1991, he argued that late modernity is characterized by intense processes of globalization and disembedding, which strongly influence the institutional composition of modern societies, as well as the very personal dispositions, emotions, and self-identities of each and every individual: "The reorganisation of time and space, plus the disembedding mechanisms, radicalize and globalize pre-established institutional traits of modernity; and they act to transform the content and nature of day-to-day social life" (Giddens 1991, 2). Giddens goes on to argue that it is a particularly demanding task of late modernity, that the self - as well as institutions and the state- - has to reflexively construct an identity "amid a puzzling diversity of options and possibilities" (Giddens 1991, 3).

In this chapter, we will scrutinize the modern task of identity building in times of globalization through the lens of ontological security. We argue that the concept of ontological security helps us to understand some of the more fundamental dimensions and dynamics of identity challenges caused by globalization. Yet, although extensive literature on ontological security is available in the fields of sociology and psychology, there is barely any geographical scrutiny or application of the concept in debates on globalization. This is all the more surprising as spatial questions are at the very core of processes of globalization and ontological security and insecurity, likewise, as we will explain further on.

Hence, in this chapter we will apply a specific geographic reading to the literature on ontological security. We thereby achieve a spatialization of the concept of ontological security, which is helpful in comprehending the role and workings of ontological (in)security in the face of globalization. Furthermore, we draw on empirical findings from our Berlin case study on ontological (in)security and geographical imaginations. Between the years 2018 and 2020, we applied the method of photo-elicitation and conducted 60 qualitative interviews and three focus groups in Berlin (Germany). In terms of the composition of our respondents, we strove for a fairly mixed sample, representing different age groups (aged 15 to 70) and gender identities equally (30 female, 30 male respondents). Only in the social composition did we strive for a rather polarized profile, capturing the geographical imaginations of globalization from 32 people with a rather marginalized background, on the one hand, in order to compare them with 28 people who can be considered elite due to their high income and cultural and social capital, on the other hand. In these interviews, we examined subjective notions of ontological security on various scales from the body to the global. ${ }^{1}$

Based on our empirical findings, we propose three spatial modes for how individuals aim to attain ontological security by geographical means: a) geopolitical positioning, b) home-making, and c) nature-related routines. The geographical imaginations are hereby central to the ways in which ontological security can be 
achieved. Hence, we argue, it is only through a spatialized, geographic understanding of ontological security that we fully grasp the complex relationships between globalization, self-identity, and ontological security. We pay particular attention to the manners in which ontological security is attained. In order to be accountable to society, the field of social sciences must not limit itself to identifying problems, but rather contribute to solving them.

\section{What is ontological security?}

Humanist psychiatrist Ronald D. Laing first developed the concept of "ontological security" in order to grasp what it takes to be, to become, and to stay mentally healthy. Having observed and treated mentally ill persons professionally, he claims that it is a certain characteristic feature that distinguishes the mentally healthy (for example non-schizophrenic) person: “ontological security” (Laing 1990, 39).

A man (sic) may have a sense of his presence in the world as a real, alive, whole, and, in a temporal sense, continuous person. As such, he can live out into the world and meet others: a world and others experienced as equally real, alive, whole, and continuous. Such a basically ontologically secure person will encounter all the hazards of life, social, ethical, spiritual, biological, from a centrally firm sense of his own and other people's reality and identity.

(Laing 1990, 39)

Using the schizophrenic as a counterpoint, Laing carves out a quintessential characteristic of mental health and personal autonomy: an existential and thus ontological posture, where an individual feels secure about her own identity, the role of other persons as counterparts in life, and the existence of a continuous environment, a (material) world around them. Thus, it is the very being-in-the-world of the subject in a "real, alive, whole, and continuous" way that the concept of ontological security grasps. Without it, mental instability or even madness lurks around the corner. Hence, ontological security is a "basic need" (Mitzen 2006a).

Anthony Giddens complements this psychological insight from a sociological perspective. He elucidates that, in our current state of late modernity, a heightened need for self-reflexivity, positioning, and identity formation is needed due to the disorienting dynamics of what geographer David Harvey has coined "time-space compression" (Harvey 1989, 4ff) and Giddens calls time-space distanciation:

Transformations in self-identity and globalization, I want to propose, are the two poles of the dialectic of the local and the global in conditions of high modernity. . . . the level of time-space distanciation introduced by high modernity is so extensive that, for the first time in human history, "self" and "society" are interrelated in a global milieu. 
Almost everyone is immersed today in a globally connected world and has to position themselves within.

This "global milieu" through which self and society now navigate their ways confronts the individual - and as other authors in political geography and international relations have argued, also the state (Huysmans 1998; Mitzen 2006a; 2006b; Hyndman and Giles 2016) — with the pressing task of (re)considering, (re)inventing, (re)building, or (re)affirming the feelings and notions of ontological security. For Giddens, this implies providing answers to existential "questions about ourselves, others, and the object-world" (Giddens 1991, 37). The less ontological security exists, the less agency is possible. Because it is only if we know who we are, and in which world we live, that we can know and decide what to do-and why. The threat of meaninglessness has to be countered by the construction of a reassuring identity. "Armed with ontological security, the individual will know how to act and therefore how to be herself" (Mitzen 2006a, 345).

Yet, if ontological security is partial, volatile, or not fully achieved by an individual, then - as Laing argues from a psychological perspective and Giddens from a sociological standpoint - anxieties are bound to arise. These anxieties are existential, because they concern the very relationship between self and world. Moreover, they are ontological, because they are rooted in the mode of being in the world. In contrast to fear, anxiety is "free floating: lacking a specific object" (Giddens 1991, 44). Hence, the very amorphous character of globalization processes, their disperse, fluid, and abstract dynamics, make them prone to stir anxieties. While fear relates to an "objective danger" that can be located in the world "out there," anxiety has no object that could be located in a particular place. "Anxiety is characterized by the fact that what threatens is nowhere" (Heidegger 2001, 231). Anxiety confronts us with our self, our being-in-the-world.

Consequently, reflecting back on some of the phenomena discussed in the introduction, such as Brexit, America First, and the rise of right-wing parties, we come to understand that these political currents, which are heavily based on nationalist identity politics, are strongly (but of course not exclusively) linked to ontological insecurity. Voting for national independency, strengthening national borders, and stirring feelings of fear towards strangers are practices of navigating the self and society through a global milieu. It involves taking a spatialized (i.e. often nationalized) stance towards global challenges and thereby fostering ontological security of the self through — equally social and territorial-exclusion.

Thus, besides other important factors such as political persuasions and racism, ontological insecurity helps to understand the multidimensional roots of rightwing populism. It particularly adds the existential dimension of the subject, its self-identity, and being-in-the-world to the discourse. Long before Brexit and similar nationalist identity movements occurred, Catarina Kinnvall was already arguing in 2004 that globalization destabilizes and even threatens self-identities and, thereby, nationalism and religious orthodoxies become "simple answers" (Kinnvall 2004, 742). She claims that people who are "uprooted from their original social milieu" and feel overwhelmed and confronted by the uncertainties of a globalized 
world could tend "to 'de-modernize," by which she means essentializing their own national or religious identity and even: "Going back to an imagined past" (Kinnvall 2004, 744). Such a backward-oriented, essentializing securitization of subject identities is as powerful as it is costly for those constructed as the inferior "Other." "Increasing ontological security for one person or group by means of nationalist or religious myths and traumas is thus likely to decrease security for those not included in the nationalist and/or religious discourse" (Kinnvall 2004, 763).

Therefore, the pressing personal and societal task of searching for ontological security in a globalized world is never innocent. It is highly power-loaded. And on that account, it bears an enormous responsibility for self and other. It is here, we argue, that a spatialized, intrinsically geographic perspective on ontological security can deeply enhance and complement the existing psychological reflections on the self and sociological reflections on late modernity. In what follows, we argue that there are particular geographical imaginations that people hold that help them to establish ontological security in a globalized world.

\section{A spatialized approach: how to achieve ontological security in a globalized world}

In our empirical research, we found particular spatial strategies that are deployed to achieve ontological security in the face of globalization in the 21st century. Drawing on insights from our interviews and inspired by a geographic reading of the relevant literature, we suggest three ways by which individuals can attain ontological security by spatial means. For this purpose, the notion of a "geographical imagination," which was profoundly conceptualized by David Harvey, is central to our argument. Because Harvey's notion of the geographical imagination elaborates what is truly at stake: the geographical imagination

enables the individual to recognize the role of space and place in his (sic) own biography, to relate to the spaces he sees around him, and to recognize how transactions between individuals and between organizations are affected by the space that separates them. It allows him to recognize the relationship which exists between him and his neighborhood, his territory, or, to use the language of the street gangs, his "turf." It allows him to judge the relevance of events in other places (on other peoples' "turf") - to judge whether the march of communism in Vietnam, Thailand and Laos is or is not relevant to him wherever he is now. It allows him also to fashion and use space creatively and to appreciate the meaning of the spatial forms created by others.

(Harvey 1973 quoted in Harvey 2005, 212)

This geographical imagination becomes central when we reassure ourselves in times of disorienting societal dynamics. In geographical imaginations, we enunciate spatial practices and routines that help us stabilize our own identities and position ourselves in the changing world. Imaginations evoke power-they shape 
practices and social orders. Moreover, imaginations are influenced by the subject's embodied intersectionality (Gieseking 2017). In what follows, we present three particular dimensions of geographical imaginations that help our interviewees to feel ontologically secure in a globalized world: through imaginations and practices of a) geopolitical positioning, b) home-making, and c) nature-related routines.

\section{Geopolitical positioning}

A fundamental task that has to be surmounted in order to establish ontological security is designing and developing a subjective understanding of the world in which the individual is living. Individuals have to situate themselves in the world. For this purpose, they require a conception of the social order in which they are living. Furthermore, an understanding of the world in the broader sense of a Weltbild helps to situate, locate, position, and thus anchor individuals in their lives. The literature often stresses the relevance of developing a notion of a social order, referring to a general idea about the normative and symbolic order of society, which helps the individual to remain ontologically secure (Huysmans 1998, 242). However, we argue that this rather non-spatial contemplation of social order does not fully address the particularly spatial identity challenges posed by globalizationneither for the individual nor for the state.

The ability to "judge the events in other places" and relate them to the spaces we see around us, as Harvey $(2005,212)$ puts it, is a truly spatial positioning of the self and a consistent topic running through our interviews in Berlin (Genz et al. 2021). We encountered many narratives of geographical imaginations-for example, Ukraine and the Russian occupation of the Crimea, the Syrian war and its consequences for the situation of refugees in Germany-where Berlin citizens of all ages, genders, and class backgrounds tried to make sense of the new world order, Berlin's situation, and their own place therein. Through photo-elicitation interviews, where representations of various spatial settings were provided as visual stimuli for narration and interpretation, it became crystal clear how extensive people's efforts were to try to make sense of major geopolitical shifts in order to achieve ontological security in their everyday lives.

In one of our interviews, a 50-year-old man who lives in a small apartment on the outskirts of Berlin provided us with his account of the 'Berlin truck attack' in the year 2016, when a truck driver deliberately drove into a Christmas market in Berlin, leaving 12 people dead and 56 injured. This assault was vividly debated in the German media, primarily in the context of rising Islamist terrorism in Europe and the United States. Our interviewee expressed his concerns in the form of a geopolitical reading and positioning of the event.

Uncertainty, ambiguous, it's both. . . I I am just saying how much has happened since the attack here [in Berlin] last year or two years ago, the Christmas market. You can understand other countries that are handling these issues differently, of course, where that doesn't happen, but as I said, we haven't had 
a war since $1945 . .$. And I don't want to experience one either, but we . . . don't know where we are heading, and there is this political uncertainty. And that was also a reason why I wanted to stay here in Germany.

(Interview B5, 143)

The perceived uncertainties and ambiguity of the new geopolitical order become visible in the interviewee's wish to attain ontological security by geographical means, geopolitical positioning, for instance: his desire to "stay here in Germany." As the interview quote illustrates, it is the very spatial dimension of our positionality and being in the world that requires reinterpretation. Particularly, the identity question has returned in its most spatial sense. This is also what the rise of nationalist populism signifies (Steger and James 2019).

Thus, as feminist dialectical thinking has argued all along, it is important to understand international politics and geopolitical events as always "co-constituted with the local, the intimate and private subjectivities" (Botterill, Hopkins, and Sanghera 2019, 468). The literature on feminist geopolitics has convincingly shown how important it is - in these uncertain and confusing times even more so- to attend to the embodied geopolitics of everyday life, and thus to scrutinize and understand the struggles and perceptions of ordinary people as part of the geopolitical (Botterill, Hopkins, and Sanghera 2019; Dowler and Sharp 2001; Hyndman 2004, 2019; Pain and Smith 2008). The interconnectedness of multiple scales related to (ontological) security run through our interviews and the narrative presentations of self as a recurring topic.

Anthony Giddens has posited that ontological security is primarily based on conceptions of social order that are part of the unconscious and practical consciousness, and enlivened in routines. Based on our research, we claim that the opposite holds true as well: people also struggle consciously and cognitively to make sense of the complex shifts in our contemporary geopolitical situation. Being reflexive and conscious about the social order and our own positioning therein creates the opportunity to reflect on privileges (being held, how they are distributed, or being lost); it could also bear the potential of an empowering moment, with the discovery of people in the same (deprived) geopolitical position. In any case, ontological security can only be attained if individuals achieve a trustworthy and reliable geographical imagination that frames and supports their positioning. To more fully understand these relations, much further feminist geopolitical research is necessary.

\section{Home-making}

Making yourself at home is yet another highly important spatial practice that is strongly linked with procuring ontological security. In our interviews, deep, subjective, emotional meanings of "home" were often brought up by the respondents as a necessary precondition for their ontological security (Pohl et al. 2020). In fact, it was often the first place they mentioned when thinking about their well-being and feeling secure. Of course, there is a variety of different factors that can enable 
the home to be a builder of ontological security. Additionally, what makes for a home has been widely discussed in the literature on housing studies and geographies of home (Blunt and Dowling 2006). The following main characteristics recur in various studies: having a private space free of surveillance; having space to live one's identity and establish it on a daily basis through recurring routines; decorating and creating one's own space in a way that reflects one's sense of belonging and identity (Dupuis and Thorn 1998, 33). Furthermore, this all strongly depends on individual characteristics, such as age, social status, gender, and cultural background. Yet, the very need for a home in order to feel secure echoes through all our interviews. The home becomes a haven to retreat to and nurture one's subjective sense of identity.

Nevertheless, feelings of being at home do not necessarily correlate with the material place of living. People refer to places they have never been as their "home" or that they have lost after moving somewhere else. Thus, for most people, a profound sense of security does not involve living at their material home as a place of residence, but rather is connected to the feeling of belonging. With regard to a more abstract understanding of home as the imagined place of belonging, we aim to sensitize present for wider notions of home through imaginations.

In urban studies, home has long since been considered a space of individualization and intimate personal development (Bahrdt 1961). Thus, it is not surprising that the home also plays a major role in shaping ontological security. Interestingly enough, though, the form of tenure is not a determining factor whatsoever. Home owners are by no means more inclined to be ontologically secure (Hiscock et al. 2001). Although the ideology of a homeowner society suggests (Saunders 1990) that homeowners feel more secure in their lives, this does not hold true when tested empirically (Behring and Helbrecht 2002; Elsvinga et al. 2007).

It was Ronald D. Laing who observed early on: "When there is uncertainty of identity in time, there is a tendency to rely on spatial means of identifying oneself" (Laing 1990, 109). Ever since, numerous studies involving homeowners, social renters, and even homeless people have confirmed that "housing can provide a fundamental building block for ontological security" (Padgett 2007, 1937). Hence, ontological security is "strongly linked to the material environment" (Dupuis and Thorn 1998, 30) and the material practices of building oneself a home-a critical source of ontological security that tends to be overlooked in most sociological or political discussions. An embodied way of expressing the own being in the world is of great importance (Giddens 1991, 53ff).

For this embodiment to take place, it is crucial to insist that no material environment can "in-itself" bring about ontological security. What it requires is a subject who feels emotionally attached to their environment - the subject has to "occupy" this place both physically and mentally.

If we narrow our home down to only one place, then there should be free space and room for oneself. Space in which you are not so restricted and can simply let your thoughts flow freely, for example. . . but otherwise, it is also 
connected strongly with feelings and people. The feeling that, if you are in this room with your best friends or your boyfriend, it can feel like home.

(Interview B20, 39)

Therefore, home is not limited to "the physical structure of a house"; rather, it relates to the moment "when such spaces are inscribed with meaning" (Easthope $2004,135)$. Hence, home always involves the subjective labor and process of homemaking in order to create a sense of ontological security through being at home.

\section{Nature-related routines}

Routines are per se a common denominator for the production of ontological security (Mitzen 2006a; 2006b, 349; Kinnvall 2004). Through the establishment of (daily) routines, frightening questions and fundamental doubts about ontological insecurity are kept at bay. In the literature, it is disputed whether these routines are rather unconscious practices, which in Giddens' terminology are enlivened as part of the practical consciousness (Giddens 1991), or whether people consciously try to establish routines in order to tackle ontological insecurity (Dupuis and Thorn 1998, 30). In any case, routines and customs are created over time. It is this trust in one's routines and habits in particular that can act as a buffer:

In the unstable world of endless change characterized by the trust deficit, the trust in habit offers a very powerful proposition on how to manage the discontinuity, how to enhance the predictability of surroundings through compressing action and how to train for embracing progression and change.

(Misztal 2019, 57)

Based on our Berlin case study, it is clear that people establish a routine in their everyday life by visiting certain places, which are often in nature. To frequent a certain walk through a park, along a river bank, a lake, or a forest path can help people to reassure themselves of where they are, who they are, and what they want to do. In doing so, this (re)assurance is often experienced through a moment of freedom and independence from social relationships with others, such as friends or family. For instance, in a quote from one of our interviews, a person talked about the reason behind his passion for lonely walks in the woods: "Because I am alone and I can breathe in nature or the smells there and I am shielded from the noise of the city" (Interview B14, 36).

Giddens already foresaw the special role nature might play in the formation of ontological security today. In spaces of nature, he claimed, people could feel at ease with their being-in-the-world (Dupuis and Thorn 1998, 28). Our interviewees in Berlin confirm this assumption. People from various age groups, genders, and social backgrounds reported that it is in spaces of nature-in the woods, at the seaside, in the mountains, or wherever personal preferences take them-where they root, regain, and recharge their ontological security. "It is calm and also alive. I love 
green. And I love nature anyway. I feel very connected, I can relax. So, I can thaw there" (Interview B13, 41). It is reasonable to assume that places in nature function as counterspaces to the highly engineered, urbanized, and fast-moving environment most of our interviewees experience in their globalized everyday lives. The possibility to see, smell, and feel utterly emerged in "pristine nature" becomes a rare opportunity against the backdrop of planetary urbanization. Especially in the Anthropocene, where it becomes increasingly difficult (if not impossible) to view nature as being separated from humanity, a new quest for nature and natural habitats might begin.

\section{Global anxieties, global identity, and global citizenship}

Globalization has changed just about everything. Through processes of international marketization, migration, communication, colonization, and economic and cultural exchange, the world has shrunk while expanding at the same time. Globalization processes have connected and uprooted, disembedded, and transformed the lives and perceptions of people around the globe. From Calcutta to Cologne, from Helsinki to Hong Kong, from Johannesburg to Rio de Janeiro: we are witnessing "the making and unmaking of new models of global citizenship" (Roy 2016, 27). This implies the many ways that people in different places, from different generations and with different social backgrounds, imagine themselves to be "empowered global citizens" who live in and shape a global milieu (Roy 2016, 27). However, in contrast to hopes for a global cosmopolitanism, in the UK, on the European continent, and in the United States, nationalism and religious orthodoxy are on the rise again (Kinnvall 2004).

In this chapter, we have used the concept of ontological security to explore the depth and extension of globalization anxieties. When we speak of ontological security, existential questions are always implied. If we scrutinize globalization anxieties as the emergence of ontological insecurity, and thus as an intrinsic dynamic in the relationship between the subject and the world, we can start to find answers to questions surrounding the new ontological positioning of the self in relation to processes of globalization and time-space compression.

Therefore, we argue that a spatialized understanding of ontological security-in other words, the use of a geographical imagination-not only will allow us to understand the immense irritations and uncertainties that are stirred up by globalization (and the fundamental spatial transformations that are evoked in turn), but also becomes an alley of thought that helps us understand how to build ontological security in times of globalization. Based on our empirical research in Berlin and a geographic reading of the literature, we have shown how immensely important a spatialized understanding of globalization anxiety is. Spatial phenomena are of utmost importance in order to understand how ontological security can be attained.

The empirical evidence from our Berlin case points towards three modes of spatial practices that people deploy to personally deal with the fundamental anxieties 
stirred by spatial transformations: a) by developing geographical imaginations of new geopolitical positionings; b) by establishing imaginative practices of homemaking and attaching meaning to home; and c) by routinely seeking out spaces in nature that help root as well as regain and charge ontological security through the reassertion of one's self-identity. We have shown how a spatial approach can help to understand these modes as particular strategies to resist the insecurities emanating from (economic) globalization. These spatial practices and strategies are ways to achieve ontological security in a globalized world with which we want to engage in the future. Our empirical research is comprised of a comparative study, in which we will also compare our Berlin findings with interviews from Singapore and Vancouver. A future task of ours will be to compare the geographical imaginations of nature, home, and geopolitical positions and their particular role for the projection of ontological security in different geographic settings.

Yet, we can already surmise from our Berlin interviews that the spatial transformation called "globalization" poses a significant challenge to most people's sense of ontological security. Though our Berlin interviewees have established for themselves meaningful geographical imaginations that help them feel ontologically secure, none of our respondents have deliberately declared themselves a "global citizen." Nobody saw their self-identity connected to cosmopolitanism or referred to themselves as Weltbürgerin (i.e. global citizen). Hence, if we reflect on the paradox that nationalist and xenophobic attitudes are on the rise in spite of globalization, it seems reasonable to argue that the spatial transformation called globalization has been fairly limited thus far. It has not achieved or led to a global identity of the (late) modern subject. The many spatial transformations and refigurations implied by globalization to date seem only to have adhered to a rather one-dimensional refiguration of institutional spaces in politics and the capitalist economy (Helbrecht et al. 2021): the establishment of tariff unions, international supply chains, immigration policies, new branches of the United Nations, and the like. Yet, at the level of the subject, limited answers to this worldwide economic and political transformation prevail, such as walking in nature, making a home, and geopolitical reasoning and repositioning. Therefore, we would argue, it is the one-sidedness of current globalization processes, i.e. their economic and political reductionism, that hinders the formation of a subjective global identity.

All things considered, since spatiality is an integral part of globalization and time-space compression, it is also within the realm of the spatiality of self, society, and world that we can find constructive answers to the current challenges and threats of ontological insecurity. To include the perspective of the everyday and the subject into research on globalization has long been an important demand of feminist scholars (Hyndman 2019). Particularly on issues of security and insecurity, the contributions from feminist geopolitics have been numerous (Williams and Massaro 2013). If we want to prevent a relapse to nationalist populist sentiments in Germany (and elsewhere) and achieve ontological security in times of globalization, it seems mandatory that we continue our move towards feminist geopolitical research. Only if we address the existential, ontological, and spatial identity challenges posed 
by economic globalization can we tackle the dangerous nationalist and xenophobic currents-on a personal as well as on a social scientific basis. This shift in perspective towards a feminist geopolitics is at least twofold. First, it includes a focus on the embodied subjects and the everyday. Second, a "feminist understanding of globalization requires substantial conceptual, analytical, and epistemological shifts" (Nagar et al. 2002, 279). By this, we mean the necessity to address globalization and the ontological insecurity it stirs as truly spatial processes that can only be fully understood through the deployment of a geographic perspective.

\section{Acknowledgements}

This research has been funded by the Deutsche Forschungsgemeinschaft (DFG, German Research Foundation)_-project number 290045248_-SFB 1265. We are grateful to Miro Born, Ylva Kürten, and Yannick Ecker for conducting the interviews we refer to in this chapter and to Henning Füller for inspirational theoretical debates in the early stages of the research project.

\section{Note}

1 For a detailed account of our research method, see Dobrusskin et al. (2021).

\section{References}

Anselmi, Manuel. 2018. Populism: An Introduction. New York, London: Routledge.

Bahrdt, Hans P. 1961. Die moderne Großstadt: Soziologische Überlegungen zum Städtebau. Opladen: Verlag für Sozialwissenschaften.

Behring, Karin, and Ilse Helbrecht. 2002. Wohneigentum in Europa. Ursachen und Rahmenbedingungen unterschiedlicher Eigentumsquoten im Vergleich. Ludwigsburg: Wüstenrot Stiftung.

Blunt, Alison, and Robyn Dowling. 2006. Home. London: Routledge.

Botterill, Kate, Peter Hopkins, and Gurchathen S. Sanghera. 2019. "Young People's Everyday Securities: Pre-emptive and Pro-active Strategies towards Ontological Security in Scotland." Social \& Cultural Geography 20 (4): 465-484.

Dirksmeier, Peter, and Ilse Helbrecht. 2015a. "Everyday Urban Encounters as Stratification Practices: Analysing Affects in Micro-situations of Power Struggles." City 19 (4): 486-498.

Dirksmeier, Peter, and Ilse Helbrecht. 2015b. "Resident Perceptions of New Urban Tourism: A Neglected Geography of Prejudice." Geography Compass 9 (5): 276-285.

Dobrusskin, Janina, Ilse Helbrecht, Miro Born, and Carolin Genz. 2021. "Bildgestützte Interviews in der Raumforschung: Potenziale der Foto-Elizitation." In Handbuch qualitativer Methoden der Raumforschung, edited by Anna J. Heinrich, Séverine Marguin, Angela Million, and Jörg Stollmann, 209-221. Bielefeld: transcript.

Dowler, Lorraine, and Joanne Sharp. 2001. “A Feminist Geopolitics?” Space and Polity 5 (3): $165-176$.

Dupuis, Ann, and David C. Thorn. 1998. "Home, Home Ownership and the Search for Ontological Security." The Sociological Review 46 (1): 24-47.

Easthope, Hazel. 2004. "A Place Called Home." Housing, Theory and Society 21: 128-138. 
Elsvinga, Marja, Jannike Toussaint, Gudrun Tegeder, and Ilse Helbrecht. 2007. "Security and Insecurity of Housing. Comparing the Netherlands and Germany.” European Journal of Housing Policy 7 (2): 173-192.

Genz, Carolin, Lucas Pohl, Janina Dobrusskin, and Ilse Helbrecht. 2021. "Geopolitical Caesuras as Time-Space-Anchors of Ontological (In)security: The Case of the Fall of the Berlin Wall.” Geopolitics (online first). doi: 10.1080/14650045.2021.1912021.

Giddens, Anthony. 1991. Modernity and Self-Identity. Stanford: Stanford University Press.

Gieseking, Jen J. 2017. “Geographical Imagination.” In International Encyclopedia of Geography: People, the Earth, Environment and Technology, edited by Douglas Richardson, Noel Castree, Michael F. Goodchild, Audrey Kobayashi, Liu Weidong, and Richard A. Marston. Oxford: Wiley-Blackwell.

Harvey, David. 1973. Social Justice and the City. Athens: University of Georgia Press.

Harvey, David. 1989. The Condition of Postmodernity: An Enquiry into the Origins of Cultural Change. Oxford: Blackwell.

Harvey, David. 2005. "The Sociological and Geographical Imaginations." International Journal of Politics, Culture, and Society 18 (3): 211-255.

Heidegger, Martin. 2001. Being and Time. Oxford: Blackwell.

Helbrecht, Ilse, Lucas Pohl, Carolin Genz, and Janina Dobrusskin. 2021. "Imaginationen der Globalisierung." In Am Ende der Globalisierung, edited by Martina Löw, Volkan Sayman, Jona Schwerer, and Hannah Wolf, 307-336. Bielefeld: transcript.

Hiscock, Rosemary, Ade Kearns, Sally MacIntyre, and Anne Ellaway. 2001. "Ontological Security and the Psycho-Social Benefits from the Home: Qualitative Evidence on Issues of Tenure." Housing, Theory and Society 18 (1): 50-66.

Huysmans, Jef. 1998. "Security! What Do You Mean? From Concept to Thick Signifier." European Journal of International Relations 4 (2): 226-255.

Hyndman, Jennifer. 2004. "Mind the Gap: Bridging Feminist and Political Geography through Geopolitics." Political Geography 23 (3): 307-322.

Hyndman, Jennifer. 2019. "Unsettling Feminist Geopolitics: Forging Feminist Political Geographies of Violence and Displacement.” Gender, Place \& Culture 26 (1): 3-29.

Hyndman, Jennifer, and Wenona Giles. 2016. Refugees in Extended Exile. London, New York: Routledge.

Kinnvall, Catarina. 2004. "Globalization and Religious Nationalism: Self, Identity, and the Search for Ontological Security." Political Psychology 25 (5): 741-767.

Laing, Ronald D. 1990. The Divided Self: An Existential Study in Sanity and Madness. London: Penguin Books.

Matthews, Julie, and Ravinder Sidhu. 2005. "Desperately Seeking the Global Subject: International Education, Citizenship and Cosmopolitanism." Globalisation, Societies and Education 3 (1): 49-66.

Misztal, Barbara A. 2019. "Trust in Habit: A Way of Coping in Unsettled Times." In Trust in Contemporary Society, edited by Masamichi Sasaki, 41-59. Leiden and Boston: Brill Academic Publishers.

Mitzen, Jennifer. 2006a. "On Ontological Security in World Politics: State Identity and the Security Dilemma." European Journal of International Relations 12 (3): 341-370.

Mitzen, Jennifer. 2006b. “Anchoring Europe's Identity: Habits, Capabilities and Ontological Security." Journal of European Public Policy 13 (2): 270-285.

Nagar, Richa, Victoria Lawson, Linda McDowell, and Susan Hanson. 2002. "Locating Globalization: Feminist (Re)readings of the Subjects and Spaces of Globalization." Economic Geography 78 (3): 257-284.

Padgett, Deborah. 2007. “There's No Place like(a)Home: Ontological Security among Persons with Serious Mental Illness in the United States." Social Science \& Medicine 64 (9): 1925-1963. 
Pain, Rachel, and Susan J. Smith, eds. 2008. Fear: Critical Geopolitics and Everyday Life. Burlington: Ashgate.

Pohl, Lucas, Carolin Genz, Ilse Helbrecht, and Janina Dobrusskin. 2020. "Need for Shelter, Demand for Housing, Desire for Home: A Psychoanalytic Reading of Home-Making in Vancouver." Housing Studies (online first). doi: 10.1080/02673037.2020.1857708.

Roy, Ananya. 2016. "Encountering Poverty." In Encountering Poverty: Thinking and Acting in an Unequal World, edited by Ananya Roy, Genevieve Negrón-Gonzales, Kweku OpokuAgyeang, and Clare Talwalker, 21-50. Oakland: University of California Press.

Sassen, Saskia, ed. 2013. Deciphering the Global: Its Scales, Spaces, and Subjects. London, New York: Routledge.

Saunders, Peter. 1990. A Nation of Home Owners. London: Unwin Hyman.

Steger, Manfred, and Paul James. 2019. "Making Sense of the Populist Challenge to Globalization." In Globalization Matters: Engaging the Global in Unsettled Times, edited by Manfred Steger and Paul James, 187-208. Cambridge: Cambridge University Press.

Verwaltungsgericht Meiningen. 2019. "Judgement from September 26, 2019.” Reference number (Aktenzeichen) 2 E 1194/19 Me. http://www.thovg.thueringen.de/webthfj/ webthfj.nsf $\mathbf{\$} \$$ webservice?openform\&vgmeiningen\&entscheidungen

Williams, Jill, and Vanessa Massaro. 2013. "Feminist Geopolitics: Unpacking (In)Security, Animating Social Change." Geopolitics 18 (4): 751-758. 